\title{
Instructional Practices, Students' Readiness and Industry Needs: Bases for an OJT Program Framework
}

\author{
Gina G. Rapatan, Roel D. Juevesa \\ Faculty, Ramon Magsaysay Memorial Colleges, General Santos City, Philippines
}

\begin{abstract}
The study designed an OJT program framework based on the instructional practices, students' readiness and industry needs. Survey, interview and documentary analysis revealed that instructional practices of the college faculty are significantly related to students' readiness. However, there was no significant relationship between students' readiness and industry needs.
\end{abstract}

The industry needs stressed that matching of OJT assignment required the link of theory and practice which emphasized time management, punctuality and promptness to meet deadlines in workplaces. Provision of ID for OJT, regular monitoring of OJT in-charge and the conduct of culmination program were highlighted to enhance the OJT program implementation.

Components of the proposed training program framework were considered in these processes: Designing OJT Program inclusive of OJT Work Analysis, OJT Module Preparation, OJT-MOA Documentation and Training series on OJT matters.

Based on the findings of the study, business education faculty are encouraged to use varied instructional practices consistently to ensure readiness of the business education students in having higher level of adaptability and employability. The study identified the need in matching the field of specialization that students get in college and the services which the industries offer for OJT. Drafting of OJT instructional manual to facilitate the framework being proposed be considered as follow-up study to this.

Keywords: Industry Needs, Instructional Practices, Students Readiness, On the Job Training Frameworks

\section{INTRODUCTION}

Education has been regarded as a means toward economic stability and progress. The increase productivity of the workforce is due mainly to the increase in the education and training of the people. The success and development of the country would greatly depend in the productivity of its human resources which is considered as one of the vital asset of the nation. Quality education and intensive training are necessary for the students to become skilled and productive workers when they become part of the labour force (Cabrera, 2012).

Business Education programmes must embrace current trends in the academic and economic demands of the society to remain relevant in providing the needs of individuals and that of the society (May, Douglas and Luth (2013). The Bologna process reflects concern of the high level educational managers' desire to modernize the process of teaching to meet requirements of labor requirements in the global market (Frank, Ofobike and Suzanne, 2010).

According to Harkrider et al (2012), Higher Educational Institutions' (HEIs) preparation must provide the technical and managerial knowledge skills that become the hallmark of professionalism. School leaders from HEIs need to design their internship program that provides the moral compasses for the company where they will eventually be employed after graduation.

In the Philippines, Higher Education Institutions (HEIs) offering business administration and management courses have been guided by the Commission on Higher Education Memorandum No. 46, series of 2012, to design their curricular programs that prepare graduates for a career in various corporations whether in 
manufacturing, marketing, or services. The College of the Business in Ramon Magsaysay Memorial Colleges in General Santos City described how the school envisions its students to join the corporate world after successfully earning the business administration and management degrees. The business education program honed business students to fully comprehend and acquired the competencies needed in the business arena in the future ( (Odunaike and Amoda 2008). As per requirement by the CHED (CMO No. 39, 2006), graduating students of business education courses need to undergo on-the-job training with required number of hours. The one-on -one interview which the researcher conducted as OJT coordinator with the Dean of the College of Business Education in RMMC confirmed that the OJT program was implemented first with Bachelor of Science in Commerce in 1966. PACUCOA survey confirmed that BSBA curricular documents submitted to CHED proved that the content of the program has undertaken modifications to align students with the requirements leading to Bachelor of Science in Business Administration based on the CMO in 2003 program in 2005. However, no tracer study or existing OJT program evaluation report could attest ensuring that BSBA curricular and instructional developments since it started documented OJT student employment thereafter.

The validation conducted by the researcher, as OJT Coordinator, among 20 pre-selected industry partners to document absorption to employment by OJT interns of RMMC found out that the OJT program of RMMC needed restructuring of the curricular content and its implementation process. The documentary analysis of OJT completion reports submitted from school year 2010-2018 by the OJT students revealed that practicumers faced challenges while having their OJT: distance of the company is too far from school or practicumer's home; time conflicts between classes and on-the-job training schedule; inadequate knowledge regarding the task assigned to the practicumer; risk of accident in the place; giving of task/s not related to the course by the partner company. Interview by the researcher with at least three practicum coordinators who used to supervise the OJT program highlighted the problems encountered in handling OJT included adjustment which students need to overcome while being placed in the new environment ; difficulty in scheduling the ocular visits in the host establishment due to different practicum sites; and difficulty in handling OJT due to lack of commonality with industry partners' company standard guidelines, policies, rules and regulations with the college.

All foregoing realities brought to light the deemed need to conduct this research to determine if academic preparations for BSBA graduates have to do with the industry work mechanisms. Emphasis was on the academe to reinforce through on-the-job training programs to fill the job openings by matching job requirements and students' knowledge, skills and attitudes was the main purpose of this study.

This is necessary to intensify the program where knowledge, skills and attitudes of business education students help them to be employable (Idialu, 2007). With this research, the framework to be designed aims to develop the learner to become productive in paid or self-employment. Amoor and Udoh (2008) said that business education could be of help to the economic development by providing knowledge and skills to the learners thereby enabling them to be responsive to the industry needs.

\section{CONCEPTUAL FRAMEWORK}

The conceptual framework characterizes the dynamism needed to imprint in producing business education graduates who could be employed in competitive business environment.

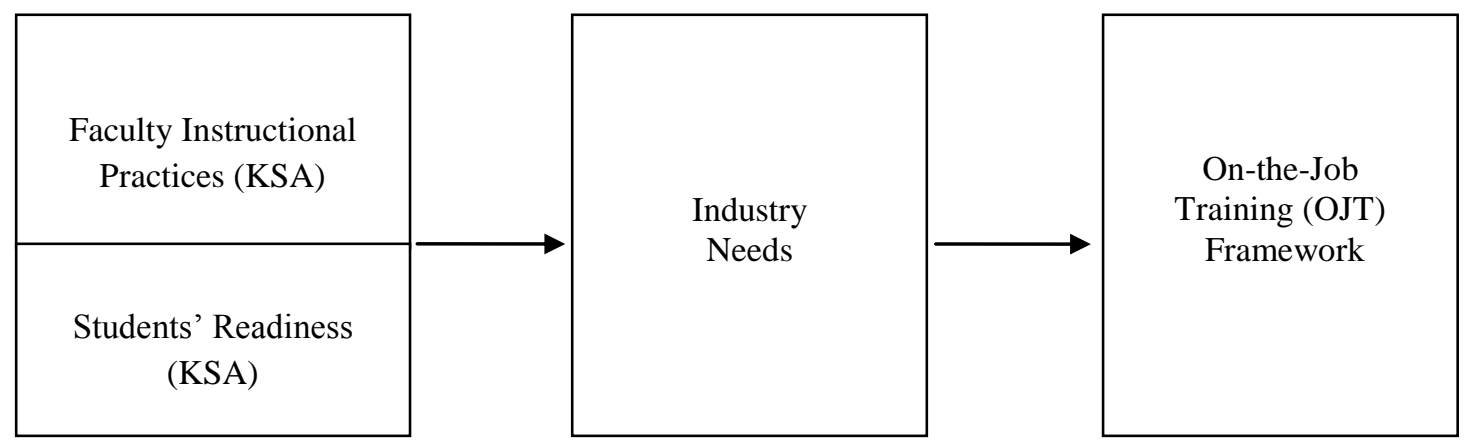

Figure 1. Conceptual Framework 
The business education college should have an emphasis on the quality of teaching and learning in order to ensure impressiveness, efficiency and productivity of education. When focusing on quality, the students' readiness to meet the industry needs be evident in their knowledge, skills and attitudes (Driscoll and Wood, 2007). Bosco et al. (2010), viewed conceptually from a process, quality instructional practices could make students ready to meet industry needs by including setting of prescribed minimum standards or benchmark, quality assurance and quality improvement.

\section{STATEMENT OF THE PROBLEM}

This study described the instructional practices, students' readiness and industry needs taking into account the students' knowledge, skills and attitudes for an On-the-Job Training program framework designed for business education students of Ramon Magsaysay Memorial Colleges.

Specifically, the study answered these questions:

1. To what extent do business education faculty utilize instructional practices to improve the knowledge, skills and attitudes (KSA) of the students of Ramon Magsaysay Memorial Colleges?

2. To what extent do business education students of Ramon Magsaysay Memorial Colleges display readiness in terms of their knowledge, skills and attitudes?

3. Are there significant relationships between these variables:

3.1 Instructional practices and students' readiness; and

3.2 Students' readiness and industry needs?

4. What are the industry needs based on the KSA of the business education students of Ramon Magsaysay Memorial Colleges?

5. Based on the findings of the study, what On-the-Job Training (OJT) program framework may be designed for business education students of Ramon Magsaysay Memorial Colleges?

\section{METHODOLOGY}

\section{Research Design}

This survey research used descriptive research. Qualitative data served as complementary to the quantitative data.

To quantify the data to be gathered, a structured questionnaire was administered to determine the instructional practices of the faculty members and students' readiness under the College of Business Administration of Ramon Magsaysay Memorial Colleges in General Santos City to meet the industry needs during their On-the-Job Training. in this study.

Industry needs were qualified using the interview guide sheet. Documentary analysis was also utilized

Qualitative research involves the collection of data subject to analysis and interpretation, focusing specifically on assessing knowledge and opinions that may not be validated statistically (Hair et al 2007).

\section{Respondents of the Study}

The data in box 1 shows the summary of the distribution of the respondents of the study. A total of twelve (12) business administration education teachers were asked to accomplish the survey questionnaire which determined their instructional practices while carrying out their teaching responsibilities among the business administration students of Ramon Magsaysay Memorial Colleges in General Santos City.

Box 1

Distribution of Respondents of the Study

\begin{tabular}{|l|c|c|c|}
\hline \multicolumn{1}{|c|}{ Groups of Respondents } & $\begin{array}{c}\text { Total } \\
\text { Population }\end{array}$ & Sample Respondents & $\%$ \\
\hline Business Education Teachers & 12 & 12 & 100 \\
\hline $\begin{array}{l}\text { Business Education Students on } \\
\text { OJT }\end{array}$ & 120 & 120 & 100 \\
\hline Industry Partners & 20 & 20 & 100 \\
\hline
\end{tabular}


Purposively, the faculty and students represented the groups of different non-probability sampling technique. The main goal of purposive sampling was to focus on particular characteristics of the faculty and students as sample population that are of interest to answer research questions concerning the instructional practices and students' readiness under the College of Business Administration of Ramon Magsaysay Memorial Colleges in General Santos City to meet the industry needs during their On-the-Job Training.

Further, the study included twenty (20) industry partners who were selected using stratified random sampling. The representatives from the industry partners were requested for an interview for supplementary notes. Stratified random sampling was used to highlight a specific subgroup of industry partners within the population of existing business establishments as partners for OJT of RMMC in General Santos City. Using the lottery method, each member of the population representing the industry partners of RMMC was assigned a unique number. The blind-folded researcher then picks 20 numbered tags from the hat. All the individuals bearing the numbers picked by the researcher are the industry partners for the study.

\section{Locale of the Study}

The locale of the study was the Ramon Magsaysay Memorial Colleges (RMMC) and its industry partners.

Ramon Magsaysay Memorial Colleges is a privately owned non-sectarian college in General Santos City. Its On-the-Job Training program was first implemented in the College of Business with Bachelor of Science in Commerce in 1966. The said course was then revised to Bachelor of Science in Business Administration based on the CMO in 2003. RMMC was given its recognition for BSBA in 2005.

The industry partners for the OJT program as an academic requirement for graduation in RMMC composed of the following: four (4) banks namely; Development Bank of the Philippines, Landbank of the Philippines, Metrobank and Philippine National Bank. First Standard Finance Corporation represents the financing industry. Three (6) industry partners were from the government namely General Santos City Water District, Government Service Insurance System, Human Resource Management and Development Office, PhilHealth, Home Development Mutual Fund and Philippine Postal Corporation. Two (2) were from the Hospital Industry namely RD Diagan Cooperative Hospital, Socsargen County Hospital and General Santos City Doctors' Hospital. Manpower services were represented solely by Investment Options Marketing Agency. Communication industry was represented by Philippine Long Distance Telephone Company. Insurance industry was represented by Charter Ping and Insurance Corporation and Malayan Insurance. Food industry was represented by Chowking KCC Gensan.

\section{RESULTS AND DISCUSSIONS Instructional Practices of Business Education Faculty}

The data in table 1, 2 and 3 contain the data in which the study described the instructional practices of the business education faculty of RMMC. The five-point rating scale was used in evaluating the seven indicators under the categories of knowledge, skills and attitude.

The factor average at 4.09 for table 1 tell that faculty made use of instructional practice for knowledge development to a high extent. Of the seven (7) instructional strategies, presentation got the highest mean from the evaluation done by the faculty and the business education students considering the mean at 4.41 and 4.44 . Presentation allows teachers and students to meet expectations of content, accuracy and accountability especially when it comes to OJT. Delivering effective presentations is dependent upon not only how good faculty or students are at transferring information but how successful they could be in influencing, inspiring and making what their ideas ,once presented, memorable and actionable for the client or prospect. 
Table 1

Instructional Practices of College Instructors for Knowledge

$\mathrm{N}=12$ teachers and $\mathrm{N}=120$ students

\begin{tabular}{|c|c|c|c|c|c|c|}
\hline $\begin{array}{c}\text { Instructional Practices } \\
\text { of College Instructors } \\
\text { for Knowledge }\end{array}$ & $\begin{array}{c}\text { College } \\
\text { Instructors } \\
\dot{x}\end{array}$ & $\begin{array}{c}\text { Verbal } \\
\text { Description }\end{array}$ & $\begin{array}{c}\text { Business } \\
\text { Education } \\
\text { Students } \\
\dot{x}\end{array}$ & $\begin{array}{c}\text { Verbal } \\
\text { Description }\end{array}$ & $\begin{array}{c}\text { Weighted } \\
\text { mean }\end{array}$ & $\begin{array}{c}\text { Verbal } \\
\text { Description }\end{array}$ \\
\hline Brainstorming & 4.33 & VHE & 4 & HE & 4.16 & HE \\
\hline Case Study & 4.08 & HE & 4 & HE & 4.04 & HE \\
\hline Colloquia & 2.75 & ME & 4 & HE & 3.38 & HE \\
\hline Discussion & 4.5 & VHE & 4.33 & VHE & 4.42 & VHE \\
\hline Presentation & 4.41 & VHE & 4.44 & VHE & 4.43 & VHE \\
\hline Recitation & 4.41 & VHE & 4.11 & HE & 4.26 & VHE \\
\hline Discovery or Inquiry & 4.08 & HE & 3.88 & HE & 3.98 & HE \\
\hline Factor Average & 4.08 & HE & 4.11 & HE & 4.09 & HE \\
\hline
\end{tabular}

\section{Legend : VHE( Very High Extent)；HE (High Extent); Moderate Extent (ME)}

Colloquium got the lowest mean with 2.75 and was practiced by the teachers to a moderate extent. Discovery or Inquiry was the instructional practice which earned the lowest mean at 3.88 based on students' evaluation. Difference of 1.13 from the two means imply that more frequent use of colloquia among teachers could facilitate students' development of knowledge about business education using discovery or inquiry.

If colloquium and inquiry are practiced, students may eventually be given responsibility for running the entire session, the teacher usually fills the role of discussion leader as students learn about seminars and questioning. Teachers could generate as many open-ended questions as possible, aiming for questions whose value lies in their exploration, not their answer. If both groups practice the two instructional strategies more often than the perceived use, results would support what the industry partners expressed in terms of having the OJT as the venue for students to put the theories they learned from school to actual workplace use.

Based on the mean ratings reflected in table 2, factor average resulted to 3.54. Demonstration, Drill and Practice at 4.33 were found to be used for instruction by the faculty to very high extent. Students' ratings at 3.88 considered field Observation, fieldwork, field trip as the instructional practice which caused the development of their skills to high extent although teachers used it to a moderate extent as evidenced by the rating at 3.08. Difference of 0.45 between the ratings for the two instructional practices, characterizes OJT as venue for students to respond with thoughts that grew of others in communal spirit to hold themselves accountable for the norms that industry partners provide during OJT. 
Table 2

Instructional Practices of College Instructors for Skills

$\mathrm{N}=12$ teachers and $\mathrm{N}=120$ students

\begin{tabular}{|c|c|c|c|c|c|c|}
\hline $\begin{array}{c}\text { Instructional } \\
\text { Instructors for Skills }\end{array}$ & $\begin{array}{c}\text { College } \\
\text { Instructors }\end{array}$ & $\begin{array}{c}\text { Verbal } \\
\text { Description }\end{array}$ & $\begin{array}{c}\text { Business } \\
\text { Education } \\
\text { Students } \\
\dot{x}\end{array}$ & $\begin{array}{c}\text { Verbal } \\
\text { Description }\end{array}$ & $\begin{array}{c}\text { Weighted } \\
\text { mean }\end{array}$ & $\begin{array}{c}\text { Verbal } \\
\text { Description }\end{array}$ \\
\hline Debate & 3.5 & HE & 3.66 & HE & 3.58 & HE \\
\hline $\begin{array}{c}\text { Demonstration Drill } \\
\text { and Practices }\end{array}$ & 4.33 & VHE & 3.55 & HE & 3.94 & HE \\
\hline $\begin{array}{c}\text { Field Observation, } \\
\text { fieldwork, field trip }\end{array}$ & 3.08 & ME & 3.88 & HE & 3.48 & HE \\
\hline $\begin{array}{c}\text { Independent Study } \\
\text { or Supervised Study }\end{array}$ & 3.08 & ME & 3.22 & HE & 3.15 & ME \\
\hline $\begin{array}{c}\text { On-line instruction } \\
\text { and learning }\end{array}$ & 2.91 & ME & 3.55 & HE & 3.23 & HE \\
\hline $\begin{array}{c}\text { Simulation } \\
\text { game/Role Playing }\end{array}$ & 4 & HE & 3.44 & HE & 3.72 & HE \\
\hline $\begin{array}{c}\text { Factor Average } \\
\text { Project }\end{array}$ & 3.55 & HE & 3.53 & HE & 3.54 & HE \\
\hline
\end{tabular}

Legend : VHE( Very High Extent) ; HE (High Extent); Moderate Extent (ME)

Factor average at 3.48 resulted from the mean ratings in table 3 based on the seven (7) instructional strategies that were practiced by faculty to develop the attitudes of business education students.

The ratings from the faculty resulted to very high extent of practice of values clarification with the mean at 4.33 and moderate extent of using journal logs at 2.50. Results imply that values clarification as an instructional practice is worth-using to improve students' attitudes with the use Journal logs which could record students' own values and beliefs and hopefully begin the process of positive change .

Students' responses generated the highest mean at 3.77 for feedback with verbal description of high extent and lowest mean at 3.00 for gallery walk with verbal description of moderate extent. Both techniques allow students to be actively engaged as they work together in small groups to share ideas and respond to meaningful questions, documents, images, problem-solving situations or texts. Students who would be qualified for OJT could be helped along the observations which the industry partners mentioned specifically pointing the area of communication, having the right attitude and observing confidentiality in dealing with documents. 
Table 3

Instructional Practices of College Instructors for Attitudes $\mathrm{N}=12$ teachers and $\mathrm{N}=120$ students

\begin{tabular}{|c|c|c|c|c|c|c|}
\hline $\begin{array}{c}\text { Instructional } \\
\text { Practices of College } \\
\text { Instructors for } \\
\text { Attitudes }\end{array}$ & $\begin{array}{c}\text { College } \\
\text { Instructors } \\
\dot{x}\end{array}$ & $\begin{array}{c}\text { Verbal } \\
\text { Description }\end{array}$ & $\begin{array}{c}\text { Business } \\
\text { Education } \\
\text { Students } \\
\dot{x}\end{array}$ & $\begin{array}{c}\text { Verbal } \\
\text { Description }\end{array}$ & $\begin{array}{c}\text { Weighted } \\
\text { mean } \\
\dot{x}\end{array}$ & $\begin{array}{c}\text { Verbal } \\
\text { Description }\end{array}$ \\
\hline Cooperative Learning & 4 & HE & 3.33 & HE & 3.67 & HE \\
\hline Feedback & 3.91 & HE & 3.77 & HE & 3.84 & HE \\
\hline Tutoring & 3.16 & ME & 3.33 & HE & 3.25 & HE \\
\hline Values Clarification & 4.33 & VHE & 3.66 & HE & 3.99 & HE \\
\hline Concept Sketches & 3.83 & HE & 3.33 & HE & 3.58 & HE \\
\hline Gallery walk & 3.08 & $\mathrm{ME}$ & 3 & ME & 3.04 & ME \\
\hline Journal logs & 2.5 & $\mathrm{ME}$ & 3.55 & $\mathrm{HE}$ & 3.02 & $\mathrm{ME}$ \\
\hline Factor Average & 3.54 & $\mathrm{HE}$ & 3.42 & $\mathrm{HE}$ & 3.48 & $\mathrm{HE}$ \\
\hline
\end{tabular}

Legend : VHE( Very High Extent)；HE (High Extent); Moderate Extent (ME)

Factor average at 3.70 in table 4 resulted from the summary of mean ratings considering the extent that business education faculty of Ramon Magsaysay Memorial Colleges utilize instructional practices to develop students' readiness in terms of their knowledge, skills and attitudes.

Table 4

Summary Table on Instructional Practices of College Instructors $\mathrm{N}=12$ teachers and $\mathrm{N}=120$ students

\begin{tabular}{|c|c|c|c|c|c|c|}
\hline $\begin{array}{c}\text { Instructional } \\
\text { Practices of } \\
\text { College } \\
\text { Instructors }\end{array}$ & $\begin{array}{c}\text { College } \\
\text { Instructors } \\
\dot{x}\end{array}$ & $\begin{array}{c}\text { Verbal } \\
\text { Description }\end{array}$ & $\begin{array}{c}\text { Business } \\
\text { Education } \\
\text { Students } \\
\dot{x}\end{array}$ & $\begin{array}{c}\text { Verbal } \\
\text { Description }\end{array}$ & $\begin{array}{c}\text { Weighted } \\
\text { mean } \\
\dot{x}\end{array}$ & $\begin{array}{c}\text { Verbal } \\
\text { Description }\end{array}$ \\
\hline Knowledge & 4.08 & HE & 4.11 & HE & 4.09 & HE \\
\hline Skills & 3.55 & HE & 3.53 & HE & 3.54 & HE \\
\hline Attitudes & 3.54 & HE & 3.42 & HE & 3.48 & HE \\
\hline Factor Average & 3.72 & HE & 3.69 & HE & 3.70 & HE \\
\hline
\end{tabular}

Legend : VHE( Very High Extent) ; HE (High Extent); Moderate Extent (ME)

Evaluation by the business education faculty and students of Ramon Magsaysay Memorial Colleges in developing their knowledge, skills and attitudes resulted to high extent of practicing the instructional practices indicators. Knowledge has the highest mean at 4.09, skills came in next with 3.54 and attitudes as the area with the lowest mean rating at 3.48. Results imply that teachers have prioritized the use of instructional practice to improve knowledge of business education students along with skills and attitudes. Although, results presented that attitudes came in last, the mean rating still suggested that teachers have used instructional practices to high extent to ensure that business education students bring with them during employment the KSA requirements as introduced and experienced during OJT. 


\section{Students' Readiness to Meet Industry Needs Based on Knowledge, Skills and Attitudes}

The second sub problem of the study dealt with the extent that business education students of Ramon Magsaysay Memorial Colleges display readiness in terms of their knowledge, skills and attitudes. Tables 6, 7 and 8 contain the data gathered concerning the readiness of the business education students' to meet industry needs considering their knowledge, skills and attitudes.

Factor average at 3.14 reflected in table 5 shows that students' readiness considering the seven (7) indicators in terms of knowledge is to moderate extent. Mean ratings at 3.91 and 4.22 were earned out of the evaluation done by the business students and industry partners respectively on the indicator concerning students' readiness to identify, prioritize and solve problems related to business management concepts. Results on students' readiness imply that teachers have to integrate in teaching business education concepts one of the things that employers often identify as being an important quality when hiring college graduates is their problem-solving skills. Students need to develop the ability to apply problem-solving skills when faced with issues or problems that are new to them. The development and use of problem-solving skills also improved learning.

The manner of identifying political and ethical implications of the decision to be made in the workplace got the lowest mean with 3.25 based on students' ratings while Identifying potential negative outcomes when considering a risky venture at 3.33 was from the industry partners' evaluation.

Table 5

Business Education Students' Readiness in terms of Knowledge

$\mathrm{N}=12$ teachers and $\mathrm{N}=120$ students

\begin{tabular}{|c|c|c|c|c|c|c|}
\hline $\begin{array}{l}\text { Business Education Students' } \\
\text { Readiness in terms of } \\
\text { Knowledge }\end{array}$ & $\begin{array}{l}\text { Business } \\
\text { Education } \\
\text { Students } \\
\dot{\mathrm{X}}\end{array}$ & $\begin{array}{l}\text { Verbal } \\
\text { Description }\end{array}$ & $\begin{array}{l}\text { Industry } \\
\text { Partners } \\
\dot{x}\end{array}$ & $\begin{array}{l}\text { Verbal } \\
\text { Description }\end{array}$ & $\begin{array}{l}\text { Weighted } \\
\text { mean } \\
\dot{x}\end{array}$ & $\begin{array}{l}\text { Verbal } \\
\text { Description }\end{array}$ \\
\hline $\begin{array}{l}\text { 1. Identify, prioritize and solve } \\
\text { problems related to business } \\
\text { management concepts }\end{array}$ & 3.91 & $\mathrm{HE}$ & 4.22 & VHE & 4.06 & $\mathrm{HE}$ \\
\hline $\begin{array}{l}\text { 2. Sort out the relevant data to } \\
\text { solve the problem }\end{array}$ & 3.91 & $\mathrm{HE}$ & 3.66 & $\mathrm{HE}$ & 3.79 & $\mathrm{HE}$ \\
\hline $\begin{array}{l}\text { 3. Identify political and ethical } \\
\text { implications of the decision to } \\
\text { be made in the workplace }\end{array}$ & 3.25 & $\mathrm{ME}$ & 3.66 & $\mathrm{HE}$ & 3.46 & $\mathrm{HE}$ \\
\hline $\begin{array}{l}\text { 4. Integrate strategic } \\
\text { considerations in the business } \\
\text { plans made. }\end{array}$ & 3.58 & $\mathrm{HE}$ & 3.88 & $\mathrm{HE}$ & 3.73 & $\mathrm{HE}$ \\
\hline $\begin{array}{l}\text { 5. Manage/oversee several } \\
\text { tasks at once and be up-to-date } \\
\text { on developments in the field. }\end{array}$ & 3.83 & $\mathrm{HE}$ & 4 & $\mathrm{HE}$ & 3.92 & $\mathrm{HE}$ \\
\hline $\begin{array}{l}6 . \quad \text { Identifying potential } \\
\text { negative outcomes when } \\
\text { considering a risky venture. }\end{array}$ & 3.75 & $\mathrm{HE}$ & 3.33 & $\mathrm{HE}$ & 3.54 & $\mathrm{HE}$ \\
\hline $\begin{array}{l}\text { 7. Monitoring progress toward } \\
\text { objectives in risk ventures. }\end{array}$ & 3.5 & $\mathrm{HE}$ & 3.55 & $\mathrm{HE}$ & 3.53 & $\mathrm{HE}$ \\
\hline Factor Average & 3.12 & $\mathrm{ME}$ & 3.15 & $\mathrm{ME}$ & 3.14 & $\mathrm{ME}$ \\
\hline
\end{tabular}

Legend : VHE( Very High Extent) ; HE (High Extent); Moderate Extent (ME) 
The results somehow are related to the area which the industry partner representative mentioned during the interview for RMMC to improve their OJT program. The following were emphasized: having the orientation with do's and don'ts in working at the bank, providing OJT students with seminars and workshops on telephone etiquette, receiving visitors in the work place, dealing with politics in the work place, maintaining confidentiality and time management .

The result also enumerates the workloads assigned to the OJT interns such as receiving calls, processing documents, using the computer although they are not at all times asked to do so. Orientation on these workloads is highly recommended by the HR representatives during the interview. The mean ratings reflected in table 6 resulted to factor average at 3.23 that shows that business education students' readiness in terms of skills is to moderate extent.

Table 6

Business Education Students' Readiness in terms of Skills $\mathrm{N}=12$ teachers and $\mathrm{N}=120$ students

\begin{tabular}{|c|c|c|c|c|c|c|}
\hline $\begin{array}{l}\text { Business Education } \\
\text { Students' Readiness in } \\
\text { terms of Skills }\end{array}$ & $\begin{array}{l}\text { Business } \\
\text { Education } \\
\text { Students } \\
\dot{\mathrm{X}}\end{array}$ & $\begin{array}{l}\text { Verbal } \\
\text { Descript- } \\
\quad \text { ion }\end{array}$ & $\begin{array}{l}\text { Industry } \\
\text { Partners } \\
\dot{x}\end{array}$ & $\begin{array}{l}\text { Verbal } \\
\text { Descript- } \\
\text { ion }\end{array}$ & $\begin{array}{l}\text { Weighte } \\
\text { d mean } \\
\dot{x}\end{array}$ & $\begin{array}{l}\text { Verbal } \\
\text { Descript- } \\
\quad \text { ion }\end{array}$ \\
\hline $\begin{array}{l}\text { 1. Convey information using } \\
\begin{array}{l}\text { appropriate } \\
\text { presentations. }\end{array}\end{array}$ & 3.75 & $\mathrm{HE}$ & 4 & $\mathrm{HE}$ & 3.88 & $\mathrm{HE}$ \\
\hline $\begin{array}{l}\text { 2. Respond to others' } \\
\text { comments during a } \\
\text { conversation or meetings. }\end{array}$ & 4.33 & VHE & 3.33 & $\mathrm{HE}$ & 3.83 & $\mathrm{HE}$ \\
\hline $\begin{array}{l}\text { 3. Work well with fellow } \\
\text { employees and supervisors. }\end{array}$ & 4.41 & VHE & 4.22 & VHE & 4.32 & VHE \\
\hline $\begin{array}{l}\text { 4. Identify sources and } \\
\text { means to resolve conflict } \\
\text { among employees. }\end{array}$ & 3.66 & $\mathrm{HE}$ & 3.65 & $\mathrm{HE}$ & 3.66 & $\mathrm{HE}$ \\
\hline $\begin{array}{l}\text { 5. Coordinate the work of } \\
\text { peers and supervisors. }\end{array}$ & 4.16 & $\mathrm{HE}$ & 3.77 & $\mathrm{HE}$ & 3.97 & $\mathrm{HE}$ \\
\hline $\begin{array}{l}\text { 6. Propose strategies to } \\
\text { business-related plans and } \\
\text { activities. }\end{array}$ & 3.58 & $\mathrm{HE}$ & 2.88 & $\mathrm{ME}$ & 3.23 & $\mathrm{ME}$ \\
\hline $\begin{array}{l}\text { 7. Provide novel solutions to } \\
\text { problems related to business }\end{array}$ & 3.58 & $\mathrm{HE}$ & 2.77 & $\mathrm{ME}$ & 3.18 & $\mathrm{ME}$ \\
\hline Factor Average & 3.39 & $\mathrm{HE}$ & 2.95 & $\mathrm{ME}$ & 3.72 & \\
\hline
\end{tabular}

\section{Legend : VHE( Very High Extent) ; HE (High Extent); Moderate Extent (ME)}

Based on the indicators, students' readiness to work well with fellow employees and supervisors got the highest mean at 4.32 or verbally described to be practiced to a very high extent. The indicator concerning the readiness to work well with fellow employees and supervisors by the OJT interns was attested to be practiced by an industry partner representative who said that the interns in their office for OJT have manifested initiative. This suggests that being able to work with the employees of the industry partner is a plus. The industry partner representative described the OJT interns were ready to handle instructions with initiative like filing workload.

The only indicator which is verbally described to be of moderate extent is students' manner of providing novel solutions to problems related to business at the lowest mean which is 3.18. Results imply that 
higher education institutions should equip graduates with the proper skills necessary to achieve success in the workplace. Industry partners expressed that higher education institutions can be held accountable in providing OJT interns briefing on the do's and don'ts of the company to ensure proper display of expected work skills. Graduates from higher education institutions are expected to possess transferable skills prior to entering the workplace. It is becoming increasingly important for graduates to be able to apply the knowledge and skills learned in higher education institutions to the workforce.

In fact, graduates perceive that many of the employability skills needed in the workforce to be more important than their actual ability to perform said skills. The factor average at 3.74 based on the mean ratings reflected in table 7 tells that business education students' readiness in terms of attitudes is to high extent. Among the indicators listed, students' readiness to function at an optimal level of performance got the highest mean at 3.96 while their manner of keeping up -to-date with external realities related to company's success. got the lowest which is 3.57 .

The results support what the industry partner representative made mention of the need for RMMC to conduct accreditation of industry partners' type of business and the students' learning opportunities during OJT . The industry partner representative expressed the need to accredit OJT interns in terms of their learning in cases like those assigned in internet café considering the qualifications that fit the company requirements. There are a number of reasons that business education graduates need to realize how OJT facilitated the importance of possessing transferable skills and assume that mastery of technical skills within disciplinary content is more important to employees.

Table 7

Business Education Students' Readiness in terms of Attitudes $\mathrm{N}=12$ teachers and $\mathrm{N}=120$ students

\begin{tabular}{|l|c|c|c|c|c|c|}
\hline \multicolumn{1}{|c|}{$\begin{array}{c}\text { Business Education } \\
\text { Students' Readiness in } \\
\text { terms of Attitudes }\end{array}$} & $\begin{array}{c}\text { Business } \\
\text { Education } \\
\text { Students } \\
\dot{x}\end{array}$ & $\begin{array}{c}\text { Verbal } \\
\text { Description }\end{array}$ & $\begin{array}{c}\text { Industry } \\
\text { Partners } \\
\dot{x}\end{array}$ & $\begin{array}{c}\text { Verbal } \\
\text { Description }\end{array}$ & $\begin{array}{c}\text { Weighted } \\
\text { mean } \\
\dot{x}\end{array}$ & $\begin{array}{c}\text { Verbal } \\
\text { Description }\end{array}$ \\
\hline $\begin{array}{l}\text { 1. Initiative change to } \\
\text { enhance productivity. }\end{array}$ & 3.50 & HE & 3.88 & HE & 3.69 & HE \\
\hline $\begin{array}{l}\text { 2. Keep up -to-date with } \\
\text { external realities related to } \\
\text { company's success. }\end{array}$ & 3.58 & VHE & 3.55 & VHE & 3.57 & VHE \\
\hline $\begin{array}{l}\text { 3. Re conceptualize role in } \\
\text { response to changing } \\
\text { corporate realities. }\end{array}$ & 3.66 & VHE & 3.55 & VHE & 3.61 & VHE \\
\hline $\begin{array}{l}\text { 4. Conceptualize a future } \\
\text { for the company. }\end{array}$ & 3.41 & HE & 3.88 & HE & 3.65 & HE \\
\hline $\begin{array}{l}\text { 5. Provide innovative paths } \\
\text { for the company to follow } \\
\text { for future development. }\end{array}$ & 3.75 & HE & 3.77 & HE & 3.76 & HE \\
\hline $\begin{array}{l}\text { 6. Function at an optimal } \\
\text { level of performance. }\end{array}$ & 3.91 & HE & 4 & HE & 3.96 & HE \\
\hline $\begin{array}{l}\text { 7. Responding positively to } \\
\text { constructive criticism. }\end{array}$ & 4 & HE & 3.88 & HE & 3.94 & HE \\
\hline $\begin{array}{l}\text { Factor Average } \\
\text { Legend : VHE(Very High }\end{array}$ & 3.69 & HE & 3.79 & HE & 3.74 & HE \\
\hline
\end{tabular}

Legend : VHE( Very High Extent) ; HE (High Extent); Moderate Extent (ME)

Skills such as solving problems, communicating effectively, working on a team, thinking critically, and possessing interpersonal skills are the employability skills most desired by employers. Skills gap is occurring 
between the demands of employment and the level of educational preparation of graduates. Functional skills were used to describe the actual functions workers perform in their specific job.

Table 8

Summary Table of Business Education Students' Readiness

$\mathrm{N}=12$ teachers and $\mathrm{N}=120$ students

\begin{tabular}{|c|c|c|c|c|c|c|}
\hline $\begin{array}{c}\text { Business Education } \\
\text { Students' Readiness }\end{array}$ & $\begin{array}{c}\text { Business } \\
\text { Education } \\
\text { Students } \\
\dot{\mathrm{x}}\end{array}$ & $\begin{array}{c}\text { Verbal } \\
\text { Description }\end{array}$ & $\begin{array}{c}\text { Industry } \\
\text { Partners } \\
\dot{\mathrm{x}}\end{array}$ & $\begin{array}{c}\text { Verbal } \\
\text { Description }\end{array}$ & $\begin{array}{c}\text { Weighted } \\
\text { mean }\end{array}$ & $\begin{array}{c}\text { Verbal } \\
\text { Description }\end{array}$ \\
\hline Knowledge & 3.12 & $\mathrm{ME}$ & 3.15 & $\mathrm{ME}$ & & \\
\hline Skills & 3.39 & $\mathrm{ME}$ & 2.95 & $\mathrm{ME}$ & & $\mathrm{ME}$ \\
\hline Attitudes & 3.69 & $\mathrm{HE}$ & 3.79 & $\mathrm{HE}$ & 3.74 & $\mathrm{HE}$ \\
\hline Factor Average & 3.4 & $\mathrm{HE}$ & 3.30 & $\mathrm{ME}$ & 3.35 & $\mathrm{HE}$ \\
\hline
\end{tabular}

Legend : VHE( Very High Extent) ; HE (High Extent); Moderate Extent (ME)

Factor average rating at 3.35 in table 8 tells that business education students' readiness in terms of knowledge, skills and attitudes is to high extent. Both business education students and industry partners considered the readiness in terms of knowledge and skills of the former to be of moderate extent based on the mean rating as 3.14 and 3.17 respectively.

Attitudes, however, got the highest mean at 3.74 and are found to be of high extent considering the readiness of students. Results restate that OJT interns' KSA could be improved by providing them related trainings and seminars. Specifically, the industry partners mentioned that OJT interns should be able to show their commitment to job in terms of their attendance. There is a need for regular monitoring of the proctor (supervising teacher for OJT) since there are a few of those interns in OJT who may be lax with finishing their assigned tasks.

\section{Industry Needs Based on Students' Competencies Reflected in Knowledge, Skills and Attitudes}

Interview results show categories of the industry needs such as the competencies under knowledge, skills and attitudes; strengths and weaknesses of the OJT program implementation while considering OJT interns' performance and the strategies identified to help RMMC improve OJT in the industry partners.

In terms of knowledge, business education students' strength was identified in terms on how OJT became a process in assigning OJT interns with clerical work than matching of workload with their field of specialization. An industry partner expressed that OJT interns were assigned with clerical works like filing and receiving phone calls sometimes processing documents not totally aligned with their field of expertise .

Results imply that OJT preparations must come from how the HEI maps the existing industry partners' services against the curricular offerings which students take as business education course. Results imply that curriculum development should be more formally delivered the outcomes advocated to inspire and enable business education students to develop their capabilities to the highest potential levels throughout life, so that they grow intellectually, are well equipped for work during their OJT.

Industry partners saw how OJT interns needed to be computer literates. Industry partners mentioned that OJT students should learn basic knowledge about computer such as spreadsheet, power point and microsoft word. 
Results from the interview on this issue confirmed that HEIs need to supplement the learning of business management concepts with literacy on tools in technology which basically become the resource for business transactions in the local and global market. Changes in technology, managerial practices, and the competitive environment have raised the level and breadth of knowledge, skills, and abilities that employers require from employees. This has further widened the already significant gap between employer needs and the actual skill levels and abilities of the graduates who enter the labor pool.

Employers recognize that some forms of training are best conducted on the job and do not expect schools to produce students with specific job skills. However, employers expect schools to produce students with the ability to use general knowledge and with traditional academic skills such as reading, mathematics, writing, oral communication, and problem solving. Roselina (2009) set the reminder to HEIs on creating awareness to graduates on the needs and expectations of the globalized job market.

Industry partners have identified having Initiative for OJT is a plus. This is worth-noting as a strength which RMMC OJT implementers need to sustain as far as the industry needs are concerned. One industry partner made mention that OJT interns have initiative in terms of acting upon instructions given.

This result bears an impression that industry partners of RMMC as business organizations often expect graduates with business education orientation to perform across a range of roles and responsibilities and must take initiative and use judgment in determining how to best satisfy customer needs and keep their team running smoothly (Baharun, Suleiman and Awang, 2012).

Industry partners also mentioned that communication skills are part of OJT workloads. Industry partner representatives pointed out that when interns have been equipped with communication skills, they could responsibly be confident in facing the clients of their companies.

The implementation of a well-planned job description that involves high level of on-the-job knowledge sharing equally proves to the employees that the organization is giving importance to knowledge sharing (Goh, Coaker and Thorpe , 2008). Industry partners also noted that interns need to make sure that their skills for OJT should be from theory to practice.

An internship combines the theory that students learned in school with practical work experience and lasts for about three months to a year (Ebreo et al, 2014). Moreover, the internship program of the college is expected to narrow the gap between the theory and practice where it should be well- crafted to cater the needs of the interns and the host institution (Batool, Ellahi, and Masood, 2012).

In terms of attitudes, the industry partners emphasized that attendance to OJT is a must. Successful implementation of on-the-job training calls for a large change in behavior, not only on the part of the OJT interns who will be trained with new methods and materials, but every organizational level as well, from the selected employees who served as partners of the OJT Program supervisors who must support the system of the industry as well as the management who implemented the system (Warinda,2013). Industry partner representatives mentioned that OJT interns should always secure permission upon absences incurred.

Industry partners also mentioned that time management in OJT is also a must. According to Robbins et. al, (2008), business education students are grouped according to their individual similarities with usual differences and each group must be given enough attention to address their individual needs based on their capabilities.

Industry partners suggested to implement the OJT program design that would develop what is missing to the skills and values of the specific students to make this undertaking worthwhile. Industry partners emphasized the value of being conscious of time and meeting deadlines. Teachers handling OJT should model on their attendance that will serve as good training for the students to value the time they need to wake up early and catch up the first lesson in the morning without being late. That habit will later become their routine until they join the workforce of professionals (Laguador, 2013).

The time management is also something to be learned in the OJT Program. By teaching students the positive impact of time management, it is something of their advantage for the future that they can apply in the workplace. Through this time management, the proper planning takes place, the expected outputs are achieved 
and there will be a positive work experience among employees. Ylagan (2013), said that the internship is the culminating academic exercise for human service students, as well as students from a variety of disciplines in two and four-year academic programs.

Strengths of the OJT program included OJT interns meet IP expectations. Industry partners mentioned their expectations on how the OJT interns work.

OJT interns provide assistance to office workloads. On-the-Job Training interns meet IP expectations. Braun and Stallworth (2009), mentioned that several industries have shared generously their company resources to impart knowledge, skills and also work values to the on-the-job trainees of the college of business education of RMMC for the past several years. The training and experiences brought by the companies to the students have contributed to the development of their attributes to become true engineers and professionals in the real work environment even for a brief period of one semester or equivalent to 600 hours.

On-the-Job Training internship has been properly documented. Industry partners with the academe looked for evidence of the following set of global core competencies: enhancing value through quality; putting ourselves in each other's shoes; sharing and collaborating; and investing in relationships.

Calhoun et. al, (2008), pointed out that today, most industries are providing opportunities for the OJT students to have hands-on training for future employment because they realize that the training of business education students is not the sole responsibility of the academe but a shared task with industry.

Brown et.al, (2010), reiterated that OJT aims to change trainees' performance through improved knowledge, skills, and attitude. Therefore, academic institutions are expected to develop useful linkages among stakeholders to assure that students are learning during the OJT program. Thus, financial support of the school, cooperation of the host organization, research of the program personnel and the business professionals' insights should serve as inputs for OJT program innovations.

On-the-Job Training interns provide assistance to office workloads. The objectives of internship are to create an opportunity to learn about a profession; and to generate values as well as substance in skills for students. It is a part-time job for specific period, paid modestly or unpaid, in which the interns gain knowledge while contributing to the organization (Curtin and Gaither, 2007).

On-the-Job Training provides students an understanding of a real business situation, but with supervision and support, industry partners recognized that OJT should produce learning outcome as "what people have learned as a result of an experience" and acknowledged their value as a means of assessing the learning that has taken place.

A number of good actions were observed among OJT Interns during their stay in the industry partners' workplace. The RMMC OJT Program helped the industry partners in so many ways like doing photocopying, filing of documents, answering phones, doing errands. The partnership, accordingly, helped the industry partners especially in dealing with back log workloads.

Here are the strategies mentioned during the interview to improve the partnership between RMMC and industry partners for OJT program implementation. First of the two (2) categories identified by the industry partner representatives was program modification. Industry partners mentioned that feedbacking could help industry partners evaluate OJT services. Moreover, successful internship programs entail finding the appropriate host training organizations where students can really learn the value of the job. Besides, it should be accompanied by proper guidance and supervisions for students to experience the right training programs within the limited period of time. Thus, the internship should entail meaningful projects that will contribute to a true learning experience, not menial tasks (Shoenfelt et.al, 2012).

One of the Industry partners mentioned the need to conduct OJT culmination program to monitor the performance of the OJT.

Another category which was identified by the industry partner representatives was reports/records management. Computer literacy is an added value to OJT internship, according to the industry partners. 
Internships and on-the-job trainings provide graduating students with first-hand experience on how real work feels like. It's an important milestone for it shapes one's professional expectations and attitude in the working world (Procknow,2012). The industry partner representatives mentioned that the OJT interns assigned in their workplace have shown knowledge on Microsoft Word basics like word and excel as evidenced by their ability to encode and transmit reports when asked.

Industry partners also cited that OJT requirements need to be clearly explained to interns . These requirements should include formal recommendation letters from the school coupled with training and proper orientation

Students were given proper orientation before they allowed to undergo their on-the-job training. One of the reminders provided to them is the proper wearing of corporate or business attire most appropriate to their respective fields and being required of them to wear in the office as uniform which make them more pleasing to the clients of certain firm (Laguador, 2013).

Employers are always looking for graduates who are good in both written and oral communications. Therefore, students should be able to develop these skills during the internship period thereby contributing to organizational success. Thus, as students will graduate, it is assumed that they build up good interpersonal skills, learn the appropriate business culture and proper communication channel in the workplace (Laguador, 2013).

Industry partner representatives suggested the inclusion of OJT trainings on personality development, communication, attitude in the workplace and the like.

In answer to the challenge of OJT Program, the colleges are expected to respond through strengthening of their academic programs and equipped students with the necessary knowledge and skills (Buted et.al, 2014). RMMC faculty training and implementation of outcomes-based education to further strengthen the capability of the students to compete with the graduates of ASEAN member countries.

The quality of the training content may not be consistent and the newcomers may never learn the standard operation procedures as a result. Industries have called for HEIS to produce new graduates with mastery of the employability skills such as communication skills, teamwork, problem solving and decision making skills. Therefore, before the graduates enter the workforce, academic institutions must ensure that these skills are already acquired by the students from formal instruction and internship programs (Beck and Halim,2008). Moreover, as stated by Pei, Daud and Jonathan (2012) if graduates were able to learn the right values and attitudes to be apply in the work environment, they are more efficient and effective leaders for future business undertakings.

\section{Significant Relationships Among and Instructional Practices, Students' Readiness \& Industry Needs}

The study determined if there was a significant relationship among the variables namely instructional practices, students' readiness \& industry needs.

Based on the data presented in table 9, there was significant relationship between instructional practices and students' readiness based on the evaluation taken from the college faculty and the students who were into OJT considering the $\dot{\mathrm{X}}=3.917$ for instructional practice and $\dot{\mathrm{X}}=4.085$ for students' readiness, $\mathrm{r}$ at 0.657 . 
Table 9

Significant Relationships Between Instructional Practices and Students' Readiness

\begin{tabular}{|c|c|c|c|c|}
\hline Variables of the study & Mean & $\mathrm{R}$ & $\mathrm{p}$ & Decision \\
\hline Instructional Practices & 3.917 & \multirow{2}{*}{0.657} & 0.0001 & reject \\
\hline Students' Readiness & 4.085 & & & \\
\hline
\end{tabular}

Significance level : $\mathrm{p}<0.05$

Therefore, the null hypothesis on these variables is rejected. This signifies that the higher extent of instructional practices, the higher that students become more ready for high on-the-job training performance while having their internship in the industry partners of RMMC. According to Torre et. al, (2014), the competence of the students is being shaped during the process of realizing the importance and appreciating the relationship of various challenges and responsibilities of their profession. Therefore, the colleges should ensure that instructional practices are well taught in the classroom for students to learn well and ready enough to face the world of business after thorough experiencing their OJT Program.

Based on the data presented in table 10 , there was no significant relationship between students' readiness and industry needs based on the evaluation taken from the students who were into OJT and the industry partners considering the $\dot{x}=3.766$ for student readiness and $\dot{x}=3.765$ for industry needs, $r$ at 0.088 . Hence, the null hypothesis is accepted.

Table 10

Significant Relationships Between Students' Readiness and Industry Needs

\begin{tabular}{|c|c|c|c|c|}
\hline Variables of the study & Mean & $\mathrm{r}$ & $\mathrm{p}$ & Decision \\
\hline Students' Readiness & 3.766 & & & \\
\hline Industry Needs & 3.765 & 0.088 & 0.75 & accept \\
\hline
\end{tabular}

Significance level : $\mathrm{p}<0.05$

Results imply that students' readiness does not have significant relationship with the industry needs. This means that the students' readiness may not at all be responsive to the needs of the industry partners. The challenge to RMMC would be to improve the existing OJT program implementation to assure the possibility of having high on-the-job training performance responsive to the needs of the industry partners. If students from business college are equipped with knowledge, skills and attitudes by the instructional practices of their teachers, the more that they could be of help to achieve the organization's mission.

\section{On-the-Job Training Program Framework}

Based on the results presented in table 11, figure 2 shows the On-the-Job Training (OJT) program framework designed for business education students of Ramon Magsaysay Memorial Colleges. 
Table 11

Summary of Findings as Basis for OJT Training Program Framework

\begin{tabular}{l}
\hline Statement of the Problem 1 \\
\hline $\begin{array}{l}\text { To what extent do Business Education Faculty utilize Instructional Practices to improve the knowledge, } \\
\text { skills and attitudes (KSA) of the students of Ramon Magsaysay Memorial Colleges? }\end{array}$
\end{tabular}
skills and attitudes (KSA) of the students of Ramon Magsaysay Memorial Colleges ?

\begin{tabular}{|c|c|}
\hline Findings & $\begin{array}{l}\text { Knowledge has the highest mean at 4.09, skills came in next with } 3.54 \text { and } \\
\text { attitudes as the area with the lowest mean rating at 3.48. }\end{array}$ \\
\hline $\begin{array}{c}\text { OJT Framework } \\
\text { Component }\end{array}$ & $\begin{array}{r}\text { Designing the On-the-Job Training (OJT) Program } \\
\text { (OJT Work Analysis, OJT Module Preparation, OJT-MOA Documentation / } \\
\text { Training series on OJT matters) }\end{array}$ \\
\end{tabular}

Statement of the Problem 2

To what extent do Business Education Students of Ramon Magsaysay Memorial Colleges display readiness in terms of their knowledge, skills and attitudes?

\begin{tabular}{|c|c|}
\hline Findings & $\begin{array}{l}\text { Students' Readiness in terms of knowledge (3.14) and skills (3.17) are of moderate extent } \\
\text { while attitudes (3.74) is of high extent. }\end{array}$ \\
\hline $\begin{array}{l}\text { OJT } \\
\text { Framework } \\
\text { Component }\end{array}$ & $\begin{array}{l}\text { Conducting the On-the-Job Training (OJT) Program } \\
\text { (General Orientation on OJT requirements and Industry Partner's Company Policies, } \\
\text { Giving of OJT Workload, Requiring OJT progress report writing) }\end{array}$ \\
\hline \multicolumn{2}{|c|}{ Statement of the Problem 3} \\
\hline \multicolumn{2}{|c|}{$\begin{array}{l}\text { What are the Industry Needs based on the KSA of the Business Education Students of Ramon Magsaysay } \\
\text { Memorial Colleges? }\end{array}$} \\
\hline Findings & Program Modification to provide trainings on KSA and Documentation \\
\hline $\begin{array}{l}\text { OJT } \\
\text { Framework } \\
\text { Component }\end{array}$ & $\begin{array}{l}\text { Evaluating the On-the-Job Training (OJT) Program } \\
\text { ( Feedbacking using interview, survey, culmination program) }\end{array}$ \\
\hline \multicolumn{2}{|c|}{ Statement of the Problem 4} \\
\hline \multicolumn{2}{|c|}{$\begin{array}{l}\text { Are there significant relationships between these variables : (1) Instructional Practices and Students' } \\
\text { Readiness; and (2) Students' Readiness and Industry Needs? }\end{array}$} \\
\hline Findings & $\begin{array}{l}\text { There was significant relationship between instructional practices and students' readiness. } \\
\text { There was no significant relationship between students' readiness and industry needs . }\end{array}$ \\
\hline $\begin{array}{l}\text { OJT } \\
\text { Framework } \\
\text { Component }\end{array}$ & Creating the Learning and Developmental Opportunity using the module for OJT \\
\hline
\end{tabular}




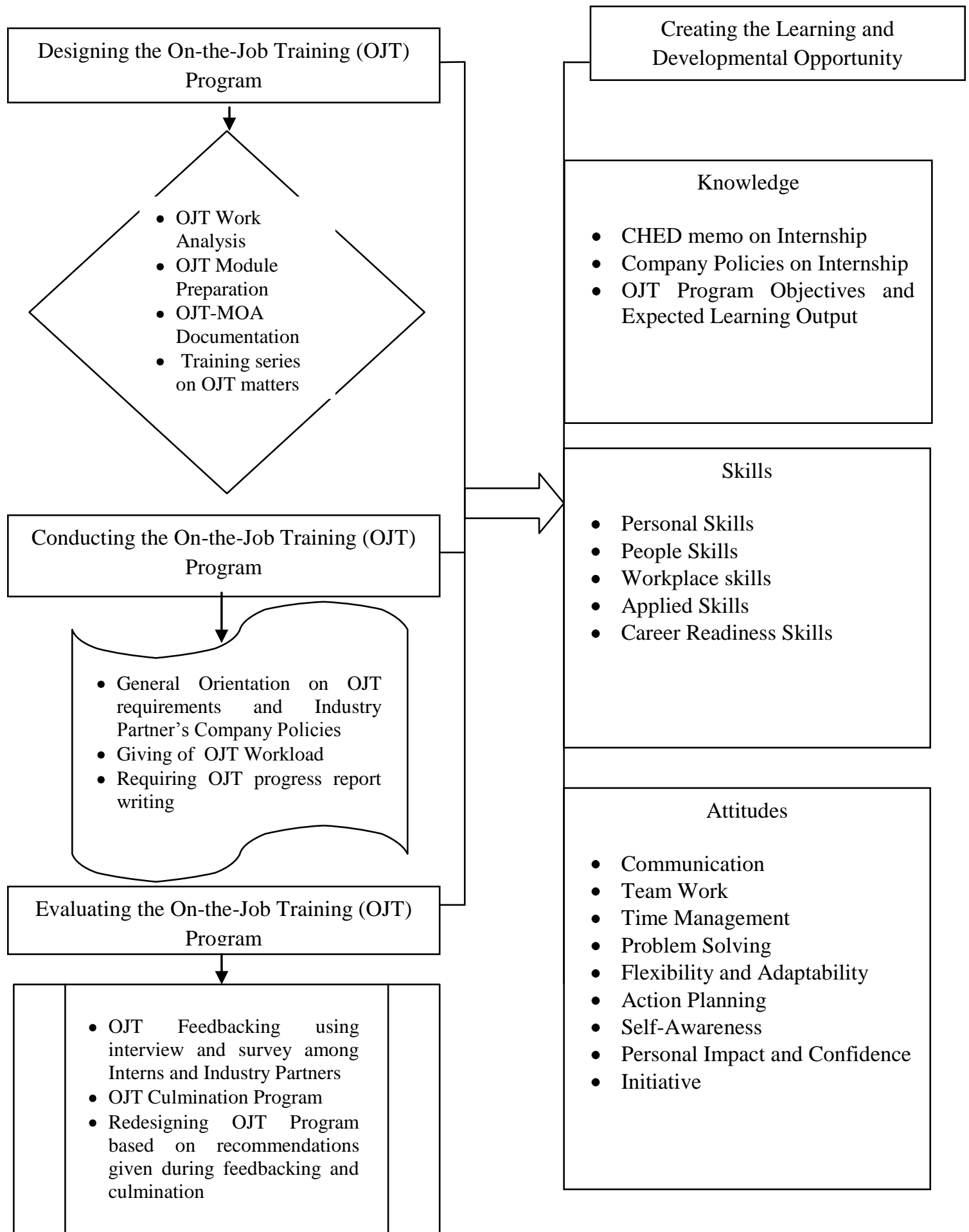

Figure 3. On-the-Job Training Program Framework 


\section{CONCLUSIONS}

The commonly used instructional practices of business education faculty for knowledge, skills and attitudes (KSA) of the students of Ramon Magsaysay Memorial Colleges are presentation, demonstration/drill/practice and values clarification respectively. high extent.

The business education students display readiness in terms of their knowledge, skills and attitudes to a

The industry needs stressed that OJT assignment must be matched with the interns' field of specialization against the existing industry positions for internship. Interns are deemed expected to use their skills in making theories practiced in their OJT. Interns need to manifest attitudes that promote time management, punctuality and promptness to meet deadlines in workplaces.

Enhancement of the implementation of the OJT program should start with provision of ID for OJT, regular monitoring of OJT in-charge and the conduct of culmination program to evaluate the OJT program implementation.

There instructional practices of the college faculty are significantly related to students' readiness. However, there was no significant relationship between students' readiness and Industry Needs.

The existing OJT program need to be reviewed and improved considering the proposed training program framework that consists of designing the On-the-Job Training (OJT) program which includes OJT Work Analysis, OJT Module Preparation, OJT-MOA Documentation and Training series on OJT matters.

\section{RECOMMENDATIONS}

The following recommendations were formulated from the conclusions and the findings of the study:

1. The faculty members are encouraged to use varied instructional practices consistently to ensure that students improve their knowledge, skills and attitudes (KSA) in dealing with learning of Business Management concepts.

2. Readiness of the business education students of the named Higher Educational Institutions (HEIs) in terms of their knowledge, skills and attitudes need to be traced from their first year until a year before their OJT to ensure their adaptability and employability level.

3. The proposed OJT training program framework is recommended to be implemented to improve the partnership of the academe and the industry partner.

4. Researchers are encouraged to be conducted in these areas:

4.1 The needs of the industry partners could be investigated further in terms of field of specialization that students get in college and the services which the industries offer for OJT.

4.2 Drafting of OJT instructional manual to facilitate the framework being proposed be considered as follow-up study to this.

\section{ACKNOWLEDGEMENT}

The authors highly acknowledge the support of the administration of Ramon Magsaysay Memorial Colleges (RMMC) in the conduct of the study.

\section{REFERENCES}

[1] Amoor S. S. And Udoh A. A. (2008). The role of secretarial education in Nigeria economic development, Journal of Educational Research and Development, 3(1): 294-298

[2] Baharun, ES Suleiman, Z Awang (2012). African Journal of Business Management 6 (30): 8789-8796.

[3] Batool, Z., Ellahi, N., \& Masood, A. (2012). National Internship Programmes and itsEvaluation: A Case Study of Punjab Region. Academic Research International , 2 (2): 562.

[4] Bosco T. A. (2014) .Pacific Journal of Cooperative Education, 2014, 15(4), 281-290). curriculum, quality of teaching and learning, work-integrated learning (WIL). 
[5] Braun, Robert \& Stallworth, Harriet. (2009). If You Need Love, Get a Puppy: A Case Study on Professional Skepticism and Auditor Independence. Issues in Accounting Education - Issues Account Educ. 24. 10.2308/iace.2009.24.2.237.

[6] Brown, et al. (2008). The impact of South Africa's ICT infrastructure on higher education . In D. Remenyi, Proceedings of the3rd International Conference of E-Learning. CapeTown, South Africa. Academic Publishing Limited.

[7] Cabrera, A. B. (2012). OJT Programs of La Consolacion College of Tanauan: Basis for Development of an OJT Manual. Unpublished Master Thesis La Consolacion College of Tanauan.

[8] Calhoun, et al. (2008). Why competencies in graduate health management and policy education? The Journal of Health Administration Education, 25(1): 17-37.

[9] CHED Memorandum Order No.46, s. 2012. Policies, Standards and Guidelines for Bachelor of Science in Business Administration (BSBA). Commission on Higher Education Memorandum 39, series of 2006

[10] Curtin, P., \& Gaither, T.K. (2007). International Public Relations : Negotiating Culture, Identity, And Power, Thousand Oaks : SAGE Publications, 1st Edition.

[11] Driscoll, A., \& Wood, S. (2007). Developing Outcomes-Based Assessment for Learner-Centered Education: A Faculty Introduction.: Creative Education, Vol.8 No.10, August 8, 2017

[12] Ebreo, et al (2014). International and Local Internship Programs of CITHM Students, Asia Pacific Journal of Education, Arts and Sciences, 1(3): 57-63.

[13] Frank, G., Ofobike, E. and Suzanne, G. (2010), “Teaching Business Ethics: A quandary for Accounting Educators”, Journal of Education for Business, Vol.85 No.3, 132-138.

[14] Goh, W Coaker, D Thorpe (2008). Proceedings of the 9th Global Congress on Manufacturing and Management, Queensland University of Technology.

[15] Hair, et al. (2014). A promising technique to interpret qualitative data in family business research. (Elsevier), 5(1):30-40.

[16] Harkrider, L. N., Thiel, C.E., Bagdasarov, Z., Mumford, M.D., Johnson, J. F., Connelly, S. and Devenport, L.D. (2012). Improving case-based ethics training with codes of conduct and forecasting content. Ethics \& Behavior, 22, 258-280.

[17] Idialu E. E. (2007), Quality Assurance in the Teaching and Examination of Vocational and Technical Education in Nigeria, College Students Journal,4(2\&3): 10-16 http://findarticles.com/p.articles

[18] Laguador, J.M. (2013). Developing Students' Attitude Leading Towards a Life-Changing Career, Educational Research International, 1(3): 28-33.

[19] Odunaike K. O. and Amoda M. B. (2008). The impact of Vocational Education on Business Education Students at Tai Solarin University of Education, Ijebu-Ode, Ogun State, Journal of Business Education and Entrepreneurial Development (JOBEED), 1 (1): 81-95.

[20] Pei, L., Daud, D., \& Jonathan, K. (2012). Perceptions of Logistics Students on Internship Programme: The Case of Private Higher Institution in Malaysia. 8.

[21] Procknow, G. (2012). "Issues with transferring knowledge acquired through workplace pedagogical interventions to on-the-job application," International Journal of Research Studies in Management, 1(1): 31-38.

[22] Robbins, et al. (2008). Prediction of College Major Persistence Based on Vocational Interests, Academic Preparation, and FirstYear Academic Performance. Res High Educ 49, 62-79.

[23] Roselina S (2009). Soft skills at the Malaysian institutes of higher learning, Asia Pac. Educ. Rev., 10 (3): 309-315.

[24] Shoenfelt, et al. (2012). Master's and Undergraduate Industrial/Organizational Internships: Data-Based Recommendations for Successful Experiences. Teaching of Psychology. 39. 100-106.

[25] Torre, M. J. U., Casas, E. S. B., Enriquez, B. S., Hernandez, C. H., \& Ilagan, G. M. (2014). Skills Requirement among Food Establishments in Batangas City, Journal of Tourism and Hospitality Research, 11(1): 76-86.

[26] Warinda, T. (2013). Accounting students' evaluation of internship experiences from a skills perspective, Asian Economic and Social Society, International Journal of Asian Social Science, 3(3): 783-799.

[27] Ylagan, A. P. (2013). Intensifying the OJT Program of the College of Business Administration, Lyceum of the Philippines University-Batangas, E-International Scientific Research Journal, 5(1): 220-220 